GLOBAL JOURNAL OF EDUCATIONAL RESEARCH VOL 19, 2020 193-205

COPYRIGHT $\odot$ BACHUDO SCIENCE CO. LTD PRINTED IN NIGERIA. ISSN 1596-6224

193 www.globaljournalseries.com; Info@globaljournalseries.com

\title{
RELATIONSHIP BETWEEN HEADTEACHER'S COMMITMENT AND LEARNERS' ACADEMIC PERFORMANCE IN PRIMARY SCHOOLS IN KERICHO COUNTY, KENYA
}

CHERUSE JOEL KIMENGICH, VIVILINE NGENO, AND KAPTINGEI SOLOMON,

(Received 11, May 2020; Revision Accepted 27, May 2020)

\begin{abstract}
The purpose of the study is to investigate the relationship between headteacher's commitment and learners' academic performance in primary schools in Kericho County, Kenya. The study was based on the transformational leadership theory. The research design employed was the convergent parallel mixed methods design. The target population consisted of 801 headteachers (524 public schools and 277 private schools) and 5933 teachers in the primary schools, 31 CSOs, 6 TSC Sub County directors and 6 MOE Sub County directors in Kericho County. Simple random and stratified sampling were used to sample 86 head teachers, Purposive sampling was used in selecting 172 teachers, 10 CSOs, 6 TSC Sub County directors and 6 MOE Sub County directors in Kericho County from Kericho County. Data was collected using questionnaires and interview schedules. Data on academic perfromance was collected using secondary data approach. Piloting was done in 9 primary schools in the neighboring Bomet County. Quantitative data was analysed using descriptive and inferencial statistics such as pearsons correlation moments and regression. Qualitative data was analyzed using textual analysis. The study established that headteachers' commitment did not have a statistically significant relationship with learners' academic performance in primary schools in Kericho County. The regression analysis were as follows. Headteachers' Commitment and learners' academic performance (Beta $=-0.012 ; p=$ $0.914)$.
\end{abstract}

\section{KEYWORDS: Headteacher's Commitment, Learners' Academic Performance, Primary Schools}

\section{INTRODUCTION}

Standard-based responsibility is now a challenge for many global practices and educational opinions. Over the past three decades, the reform of national education has resulted in a rigorous goal for all students in the main thematic areas and measures of accountability, including restrictions for schools that have not made sufficient progress in achieving their goals (Herrera, 2010). In the culture of environmental organization increasingly critical to the school, the National Teachers' Association (NAHT) in the United Kingdom conducted research to identify, study and celebrate good leadership practices (Robinson, 2011).

Cheruse Joel Kimengich, University of Kabianga

Viviline Ngeno, Department of Education planning, Management and Foundation, and Psychology, University of Kabianga

Kaptingei Solomon, Department of Curriculum Instructions and Educational Media, University of Kabianga 
The Global Education Monitoring Report (EFA), implemented in 2005, which focuses on quality and primary education, is a strong indicator of leadership and emphasizes the leadership of school leaders in influencing students' performance at school (Alexander, 2015). Leadership behavior is the process of influencing and directing the human resources of institutions, especially faculties, non-faculties and students, in order to achieve academic excellence for the purpose of general educational purposes (Day, 2011). The success of the institution depends on the leader's leadership, which is determined by other stakeholders.

\section{Statement of the Problem}

In Kenya, learner performance in primary schools has remained unimpressive despite efforts by the government to ensure quality leadership in the schools. This is happening when it is quite clear that Headteacher's leadership plays an integral role in education sector worldwide. Kericho County has 80 of the primary schools under this programme. In addition, quite a number of schools in Kericho County did perform poorly in $\mathrm{KCPE}$ in the last five years. Studies in Kericho county revealed that Secondary schools principals possess transformational leadership competences, however, limited studies are available in Kericho county pertaining the relationship between headteacher's commitment and learners academic performance in primary schools. It is because of this basis that the researcher found out that this study was necessary for filling the knowledge 'gap'. Therefore, the sole purpose of this study was to investigate the relationship between headteacher's commitment and learners' academic performance in primary schools in Kericho County, Kenya.

\section{Null hypotheses}

$\mathbf{H}_{01}$ : There is no statistically significant relationship between headteachers' commitment and learners' academic performance in primary schools.

\section{Objective of the Study}

To determine the relationship between headteacher's commitment and learners' academic performance in primary schools in Kericho County, Kenya.
LITERATURE REVIEW

Head teachers Commitment and Learners'

Academic Performance

Commitment is basically loyalty and connection with the organization (Pandey, 2012). In the context of the school, the degree to which teachers identify with their institution and the willingness to continue work or school vision. The organization's dedication has three dimensions of gathering, which are affective, persistent and normative commitments (Jaros, Meyer and Allen, 2007).

Research in the teaching area in Pakistan shows that both transformation and transactional leadership has a high quality of sacrifice (Rehman and Waheed, 2012). Among the factors determining commitment to work, leadership is considered an indispensable predictor and plays a major role. Employee satisfaction depends on the leaders' leadership. This affects employees who work in difficult conditions, ensuring optimal performance.

According to Wagner and Ruch (2015), commitment is described as behaviorally illustrated with the help of school principals who have appropriate personality traits, are admired, respected and dependent on society. This full community, teachers, and such directors are proud of its importance. The privileged effect occurs where the director's performance affects new people and the full group of employees, by real expressing imagination and prejudice shared with teachers, referring to their hobby values with the belief of leaders.

Kim, Altmann and Hwang, (2010) mentioned in their study, which resulted in devoting two transformation leadership competences in the high school in the Kirinyaga district, confirming that the majority of the heads and the teachers did not get or exploit the idealization affecting the leadership effectiveness Transformation at school is therefore difficult to determine if it affects the obligations of a coaching employee. This style is a new idea for many people in manger management. Learning to draw the conclusion that teachers want to become expert leaders and commit themselves to leadership in overcoming human and material resources.

According to Ongong and Akaranga, involvement in work (2013) is a procedure in which employees 
internalize their work values in institutions and believe that life in an institution is a moral responsibility. Then they noticed that the involvement of employees in the group wanted to play a vital role in the institution. They want to have an impact on the educational institution's program or strategy. The dedication of work has potential employees identified with their organizations working towards a permanent commitment to employees living in institutional institutional institutions.

With regard to headteachers commitment, it emerges that reviewed studies did not focus on the relationship between the headteachers' commitment and learners' academic performance in primary schools. Furthermore, the studies were carried out in a different geographical location from Kenya, and thus the aspects of commitment may not be generalized.

\section{Theoretical Framework}

The study is informed by the theory of transformational leadership developed by James MacGregor Burns in 1978. According to the theory Transactional leaders focus on gaining compliance by giving and withholding rewards and benefits, and have exchange relations with their supporters. According to the theory employees tend to imitate their leaders, and thus in this study meadership commitment has a positive influence on teachers' commitment, and subsequently enhanced learners' academic performance. Leaders are encouraging supporters to go beyond self-interest for the benefit of the team or organization.

\section{RESEARCH METHODOLOGY}

This study adopted a Convergent mixed methods approach, and embraced the tenets of pragmatism philosophical worldview. The target population consisted of 6 sub-county TSC directors, 6 sub-county Ministry of Education directors, 31 CSOs, 801 headteachers and 4271 teachers in 801 primary schools (444 performing schools, 80 schools under School Improvement Programme; and 277 private schools) in Kericho County.

Stratified sampling technique was adapted whereby, strata namely TSC sub-county directors, Ministry of Education Sub county directors, CSOs and headteachers were utilized. Schools were stratified as performing schools, schools under School Improvement Programme (SIP); and private schools. All the three categories of schools sample were selected using simple sampling technique. The schools were clustered according to the six clusters (sub- county) namely; Kericho, Belgut, Bureti, Soin/Sigowet, Kipkelion and Londiani. The computed sample size was distributed to the six clusters. TSC sub-county directors, CSOs and Ministry of Education Sub County Directors were selected using purposive sampling technique.

The sample size for headteachers was calculated using a scientific formula by (Kothari, 2004) giving rise to a sample of 95 teachers. The sample for CSOs was computed using a recommendation by Gall, Gall, and Borg (2007), who recommends $30 \%$ of the population for interviews. In this case, $30 \%$ of 31 CSOs translated to 9.30 . Therefore $10 \mathrm{CSO}$ were used for the study.

Two teachers were reached per school (94 teachers divided by 86 schools $=1.146341463$ ) . Therefore, the sample size comprised of 82 primary school headteachers, and 172 teachers (from 96 teachers from perfroming schools, 18 teachers from SIP schools and 60 teachers from private schools) and all the 6 TSC sub-county directors and 6 Ministry of Education Sub county directors, and 10 CSOs in Kericho County.

Data was collected using questionnaires, interviews, observation checklists and pupils academic records. These tools were developed by the researcher and was administered to the head teachers and teachers. Prior to collection of data the instruments were pilot tested and subjected to validity checks and reliability tests. The tool for headteachers was adopted given that the score of 0.768 was higher than the recommended correlation coefficient at 0.7 , while that for teachers was adopted given that the score of 0.896 was higher than the recommended correlation coefficient at 0.7 .

The researcher obtained a letter of approval from the University of Kabianga to be presented to the National Commission of Science and Technology Innovation (NACOSTI) for clearance. Permission was sought from the sub-county office, TSC county Director, Kericho County and the County Commissioner, Kericho County. The researcher met all the relevant authorities.

Data was analyzed both qualitatively and quantitatively. Quantitative analysis data was analyzed using descriptive statistics such as percentages and frequencies. The researcher utilised inferential and descriptive statistics for data analysis. Inferential statistics constituted Pearson correlation ( $r$ ) and Regression analysis. The associations depicted by Pearson correlations was considered statistically significant when the sig. / $p$ value is less than $0.05(p<0.05)$. The regression analysis involved 
the computation of the ANOVA, t-tests, Beta value $(\beta)$, as well as the $p$ values. The results from the analysed quantitative data was presented using graphs, pie charts, frequencies, tables and figures. Qualitative data generated from the open ended questions in the research instruments, was organized in themes and patterns categorized through textual analysis.

The researcher ensured that participants are treated with utmost respect and that they were fully aware that their participation is voluntary and can withdraw at any stage of the data collection process. The researcher also ensured that there was informed consent with the respondents and voluntary participation. Confidentiality was also assured and maintained. The respondents were not required to write their names on the questionnaires to ensure that anonymity is upheld.

\section{RESULTS AND DISCUSSIONS \\ Respondents Response Rate}

The response rate is averaged at $89.83 \%$. The study targeted 86 . Head teachers and obtained a response from 78 head teachers. The study was able to obtain a response from 153 teachers out of the targeted 172 teachers. The response was above $75 \%$ responsec rate recommended by Dommeyer, Baum and Hanna (2002) for paper surveys.

\section{Demographic Characteristics}

The results show that majority of the respondents were aged 31 to 40 years, $69.2 \%$ of the headteachers and $46.8 \%$ of the teachers were male, while $30.8 \%$ of the headteachers and $53.2 \%$ of the teachers were female. The results suggest that the heaviest distribution of headteachers was between diploma level and degree level, while that of the teachers stretched between certificate level and diploma level.

\section{Descriptive Statistics for Headteacher's Commitment}

The results in Table 6 from the headteachers' responses show that the statement suggesting that headteachers reported to work early recorded a mean score of 4.4615 . The value is far much more than the 3.0 neutral mean score. This suggests that according to majority of the headteachers, they headteachers reported to work early. The results are in agreement with those in a study by Awiti (2016) who established that the headteachers reported to school on time and this enabled them supervise teachers' punctuality.

The results in Table 6 from the headteachers' responses show that the statement suggesting that coordination was ensured on teachers recorded a mean score of 4.3205 . The value is far much more than the 3.0 neutral mean score. This suggests that majority of the headteachers ensured proper coordination of teachers in their respective schools. The results are similar to those in a study by Nzambi (2012) who reported that headteachers were commited to the task of coordination of teacher functions.

The results in Table 6 from the headteachers' responses show that the statement suggesting that they involved all teachers in decision making recorded a mean score of 4.2436 . The value is far much more than the 3.0 neutral mean score. This suggests that majority of the headteachers involved all teachers in decision making in their respective schools. This similar to a study by Wadesango, Mutekwe, Ndofirepi, Maphosa and Machingambi (2017) where it was found out that headteachers involved all teachers in decision making.

The results in Table 6 from the headteachers' reponses show that the statement suggesting that they were friendly and easy to dialogue with recorded a mean score of 4.3590 . The value is far much more than the 3.0 neutral mean score. This suggests that majority of the headteachers were friendly and easy to dialogue with in their respective schools. The results are in agreement with those in a study by Day (2011) where it was found out that head teachers communicate effectively and act in a friendly manner.

The statement implying that that headteachers delegate school duties without favor recorded a mean score of 4.4615 . The value is far much more than the 3.0 neutral mean score. This suggests that majority of the headteachers delegate school duties without favor in their respective schools. The results are similar to those in a study by Robinson (2011) who established that in most of the schools, the headteachers perfected the art of delegation of duties indiscriminately.

The statement implying that that headteachers express confidence in staff members recorded a mean score of 4.3974 . The value is far much more than the 3.0 neutral mean score. This suggests that majority of the headteachers express confidence in staff members in their respective schools. The results are similar to those in a study by Maingi (2016) who reported that in most of the schools the headteachers expressed confidence in their staff members, and this approach helped build staff confidence in their job makes the followers to be effective on their job. 
The statement implying that that headteachers are good listeners to staff members recorded a mean score of 4.4744 . The value is far much more than the 3.0 neutral mean score. This suggests that majority of the headteachers indicated that they were good listeners to staff members.

The results are in agreement with thaose in a study by Day (2011), whereby it was established that majority of the headteachers were considerate and supportive, listening to teachers' ideas. The statement implying that headteachers are open to criticism by staff recorded a mean score of 4.2949. The value is far much more than the 3.0 neutral mean score. This suggests that majority of the headteachers indicated that they were open to criticism by staff.

The statement implying that that headteachers promote co-operation among staff recorded a mean score of 4.4744 . The value is far much more than the 3.0 neutral mean score. This implied that majority of the headteachers indicated that they were promoted co-operation among staff in their respective schools.

The statement implying that that headteachers created harmony and unity in the staff recorded a mean score of 4.3333 . The value is far much more than the 3.0 neutral mean score. This implied that majority of the headteachers indicated that they created harmony and unity among the staff in their respective schools. The results are similar to those in a study by Oduk (2016), whereby it was established that most of the headteachers created harmony and unity in the staff, and that they did it always and often respectively.

The results in Table 6 show that the statement implying that headteachers properly allocated work to teachers recorded a mean score of 4.4359. The value is far much more than the 3.0 neutral mean score. This implied that majority of the headteachers indicated that they properly allocate work to teachers in their respective schools. The results in Table 6 show that the statement implying that that headteachers ensured that teachers meet the required goals recorded a mean score of 4.9744 .

The results in Table 6 show that the statement implying that headteachers give procedures to be followed recorded a mean score of 4.3974 . The value is far much more than the 3.0 neutral mean score. This implied that majority of the headteachers give procedures to be followed in their respective schools. The results are in agreement with those in a study by Alabu (2012), where it was pointed out that teacher effectiveness was greatly influenced by the policies and procedures provided to them by the head teachers.

The results in Table 6 show that the statement implying that headteachers ensured that teachers complete the syllabus recorded a mean score of 4.6026. The value is far much more than the 3.0 neutral mean score. This implied that majority of the headteachers ensured that teachers complete the syllabus. The results were contrary to those in a study by Nzambi (2012) who found out that in most schools, there was failure of syllabus coverage an indication of headteachers' failure to ensure that teachers completed the syllabus.

The results in Table 6 show that the statement implying that headteachers supervise and direct teachers recorded a mean score of 4.5897 . The value is far much more than the 3.0 neutral mean score. This implied that majority of the headteachers supervise and direct teachers. The results are in agreement with the findings in a study by Kimeu (2018), where it was found that headteachers supervise and direct teachers as per set education policies and guidelines.

The results in Table 6 show that the statement implying that headteachers allocate work to teachers recorded a mean score of 4.6026 . The value is far much more than the 3.0 neutral mean score. This implied that according to majority of the headteachers, they allocate work to teachers. Robinson (2011) stressed that essence of headteachers allocation of work to teachers, for if not properly done, it affected the achievement of set school goals. 
Table 1: Descriptive Statistics for Headteacher's Commitment

\begin{tabular}{llll}
\hline & N & Mean & Std. Dev. \\
\hline Report to work early & 78 & 4.4615 & .78446 \\
Coordination is ensured on teachers & 78 & 4.3205 & .74718 \\
Involve all teachers in decision making & 78 & 4.2436 & .82471 \\
Friendly and easy to dialogue with & 78 & 4.3590 & .78912 \\
Delegate school duties without favor & 78 & 4.4615 & .73312 \\
Express confidence in staff members & 78 & 4.3974 & .67111 \\
A good listener to staff members & 78 & 4.4744 & .81741 \\
Open to criticism by staff & 78 & 4.2949 & .96845 \\
Promote co-operation among staff & 78 & 4.4744 & .63908 \\
Create harmony and unity in the staff & 78 & 4.3333 & .75018 \\
Properly allocate work to teachers & 78 & 4.4359 & .71332 \\
Ensure teachers meet the required goals & 78 & 4.9744 & 5.66368 \\
Give procedures to be followed & 78 & 4.3974 & .67111 \\
Ensure teachers complete the syllabus & 78 & 4.6026 & .61030 \\
Supervise and direct teachers & 78 & 4.5897 & .54501 \\
Allocate work to teachers & 76 & 4.6974 & .51691 \\
Valid N (listwise) & 75 & & \\
\hline
\end{tabular}

Teachers' Response on Headteachers' Commitment

The results provided in Table 7 show that the statement implying that Headteachers' punctuality to school had an influence on learners' performance recorded a mean score of 4.3289. the mean score was higher that the 3.0 neutral mean score. The implication was that Headteachers' punctuality to school had an influence on learners' performance.

As shown in Table 7, the statement implying that Headteachers' ability to formulate and shape the future had an influence on learners' performance recorded a mean score of 4.1351 . The mean score was higher that the 3.0 neutral mean score. The implication was that headteachers' ability to formulate and shape the future had an influence on learners' performance.

The results in Table 7 show that, the statement implying that Headteachers' great determination and willpower to see things through had an influence on learners' performance recorded a mean score of 4.1554 . The mean score was higher that the 3.0 neutral mean score. The implication was that headteachers' great determination and willpower to see things through had an influence on learners' performance.

The results in Table 7 show that the statement implying that Headteachers' commitment to developing personal strategies especially during difficult situations had an influence on learners' performance recorded a mean score of 4.0940 . The mean score was higher that the 3.0 neutral mean score. The implication was that Headteachers' commitment to developing personal strategies especially during difficult situations had an influence on learners' performance.

The results in Table 7 show that the statement implying that Headteachers' ability to go an extra mile to solve school problems had an influence on learners' performance recorded a mean score of 4.2617. The mean score was higher that the 3.0 neutral mean score. The implication was that Headteachers' ability to go an extra mile to solve school problems had an influence on learners' performance. 
Table 2: Teachers' Response on Headteachers' Commitment

\begin{tabular}{llll}
\hline Headteachers' & N & Mean & Std. Dev. \\
\hline Punctuality to school & 149 & 4.3289 & .85774 \\
$\begin{array}{l}\text { Ability to formulate and shape the future } \\
\text { Great determination and willpower to see things }\end{array}$ & 148 & 4.1351 & .81356 \\
through. & & 4.1554 & .85486 \\
$\begin{array}{l}\text { Commitment to developing personal strategies } \\
\text { especially during difficult situations }\end{array}$ & & 4.0940 & .86479 \\
$\begin{array}{l}\text { Ability to go an extra mile to solve school problems } \\
\text { Valid N (listwise) }\end{array}$ & 149 & 4.2617 & .92558 \\
\hline
\end{tabular}

\section{KCPE Trends for the last 5 years}

An analysis of the average mean scores for KCPE Performance for the last 5 years (2013 2017) was as conducted. The results in Table 8 and Figure 4 shows that the average mean scores for KCPE Performance for the last 5 years was as follows: year 2013 (242.4863), year 2014
(240.2092), year 2015 (248.3190), year 2016 (251.9441), and year 2017 (250.0521). The results depict a progressive trend in KCPE performance up to 2016. The lowest mean grade was registered in the year 2014, while the highest was in
2016.

Table 3: KCPE Performance for the last 5 years

\begin{tabular}{llllll}
\hline Year & N & Minimum & Maximum & Mean & Std. Deviation \\
\hline 2013 & 78 & 110.00 & 318.79 & 242.4863 & 36.23840 \\
2014 & 78 & 115.05 & 339.26 & 240.2092 & 37.75458 \\
2015 & 78 & 122.00 & 345.26 & 248.3190 & 39.12000 \\
2016 & 78 & 150.50 & 336.63 & 251.9441 & 38.65314 \\
2017 & 78 & 147.31 & 333.61 & 250.0521 & 40.51674 \\
Valid N (listwise) & 78 & & & & \\
\hline
\end{tabular}

KCPE Performance for the last 5 years per School Type

The results in Table 9 and Figure 5 show that private primary schools in Kericho Countyhad the best average mean score across 5 years, at 264.55 , followed by public primary schools at 241.58, and then primary schools in the SIP category at 221.04. Even though the mean score for the primary schools in the SIP category was below the mid mark of 250 . The results also show that the average for the public primary schools under investigation has remained below the 250 across the five years $(2013$ - 2017). The performance has remained below average in public primary schools and special improvement plan (SIP) schools, while private primary schools continue to perform better. The drop in performance in the year 2017 was observed in public primary schools and special improvement plan

(SIP) schools 
Table 4: KCPE Performance for the last 5 years per School Type

\begin{tabular}{llll}
\hline Year & \multicolumn{2}{l}{ Type of School } & \\
& Public & Private & SIP \\
\hline 2013 & 239.96 & 255.82 & 218.40 \\
2014 & 237.21 & 257.21 & 208.59 \\
2015 & 242.04 & 268.07 & 223.35 \\
2016 & 245.17 & 271.74 & 228.94 \\
2017 & 243.51 & 269.89 & 225.94 \\
Average Mean & $\mathbf{2 4 1 . 5 8}$ & $\mathbf{2 6 4 . 5 5}$ & $\mathbf{2 2 1 . 0 4}$ \\
\hline
\end{tabular}

Teachers' description of Learners'

Using select learners' performance indicators, teachers were asked to describe learners' performance in their respective schools. The results for performance provided in Table 10 were as follows: Learners performance in national examiniations (2.4641); learners' retention rates (2.7778) and learners' level of discipline (2.4706). The results suggest that learners performance along the measured indicators were unimpressive across the county.

Table 5: Teachers' description of Learners' Performance

\begin{tabular}{llll}
\hline & N & Mean & Std. Deviation \\
\hline Learners performance in national examiniations & 153 & 2.4641 & .86622 \\
Learners' retention rates & 153 & 2.7778 & .90483 \\
Learners' level of discipline & 153 & 2.4706 & .77848 \\
Valid N (listwise) & 153 & & \\
\hline
\end{tabular}

\section{Correlation between Headteachers'} Commitment and Learners' Performance

The findings in Table 11 shows that there was a positive correlation between headteachers' commitment and learners' performance at $r=$ $0.045 ; p=0.579$. Given that the $p$ value was higher than the test significant value at 0.05 , the correlation is interpreted to be statistically insignificant. The results suggest that there was a positive association between headteachers' commitment and learners' performance. However, this association was insignificant. The results are contrary to the findings by Day (2011) who found a significant association between headteachers' commitment and learners' performance.

Table 6: Correlation between Headteachers' Commitment and Learners' Performance

\begin{tabular}{llll}
\hline & & $\begin{array}{l}\text { Headteachers' } \\
\text { Commitment }\end{array}$ & $\begin{array}{l}\text { Learners' } \\
\text { Performance }\end{array}$ \\
\hline Headteachers' & Pearson Correlation & 1 & .045 \\
Commitment & Sig. (2-tailed) & & .579 \\
& $\mathrm{~N}$ & 153 & 153 \\
Learners' Performance & Pearson Correlation & .045 & 1 \\
& Sig. (2-tailed) & .579 & 153 \\
& $\mathrm{~N}$ & 153 & \\
\hline
\end{tabular}


Regression Analysis

Multiple regression analysis was done to establish the relationship between the headteacher's commitment, and learners' academic performance in primary schools.

\section{Model Summary}

The R Square value in the Model Summary table shows the amount of variance in the learners' performance that can be explained by headteachers' commitment. The independent variables listed below Table 12 accounted for .04 percent of the variability in learners' performance.
The R-value (.06) is the correlation coefficients between headteachers' commitment and learners' academic performance. The $R$ value of 0.6 show a low The results show low regression between these variables. The Adjusted R Square adjusts for a bias as the number of variables increases. The Std. Error of the Estimate is a measure of the accuracy of the prediction. In this case it is small thus implying that the population is more uniform, so your sample mean is likely to be close to the population mean.

\section{Table 7: Model Summary}

\begin{tabular}{lllll}
\hline Model & $\mathrm{R}$ & $\mathrm{R}$ Square & Adjusted R Square & Std. Error of the Estimate \\
\hline 1 & $.060^{\mathrm{a}}$ & .004 & -.003 & .60091 \\
\hline
\end{tabular}

a. Predictors: (Constant), Headteachers' Commitment

\section{Analysis of Variances (ANOVA)}

In the study, the predictors are significant when Sig. ( $p$ value) $p<0.05$. The findings in Table 13 show that $p$ value was 0.459 . Since the $p$ values are higher than 0.05 (confidence level), we can conclude that the the relationship between headteachers' commitment and learners' academic performance in primary schools in Kericho County is insignificant. As $p>0.05$ headteachers' commitment is not significantly better than would be expected by chance. The regression line predicted by headteachers' commitment explains an insignificant amount of the variance in learners' academic performance in primary schools. This is reported as follows: $F$ $(1,151)=0.551 ; p>0.05$, and therefore can conclude that the regression is statistically significant.

Table 8: Analysis of Variances (ANOVA)

\begin{tabular}{|c|c|c|c|c|c|c|}
\hline \multicolumn{2}{|c|}{ Model } & Sum of Squares & df & Mean Square & $\mathbf{F}$ & Sig. \\
\hline \multirow[t]{3}{*}{1} & Regression & .199 & 1 & .199 & .551 & $.459^{6}$ \\
\hline & Residual & 54.526 & 151 & .361 & & \\
\hline & Total & 54.724 & 152 & & & \\
\hline
\end{tabular}

a. Dependent Variable: Learners' Performance

b. Predictors: (Constant), Headteachers' Commitment

\section{Beta Coefficients}

The following regression model was used

$Y=\beta_{0}+\beta_{1} \mathrm{HC}+\varepsilon$

$Y=2.262+0.045+0.257$

From the findings, it emerges that the most influential determinant of Learners' Performance was Headteachers' Commitment (Beta $=-0.012 ; p=0.914)$. 
Table 9: Beta Coefficients

\begin{tabular}{|c|c|c|c|c|c|}
\hline Model & \multicolumn{2}{|c|}{$\begin{array}{l}\text { Unstandardized } \\
\text { Coefficients }\end{array}$} & \multirow{2}{*}{$\begin{array}{l}\text { Standardized } \\
\text { Coefficients } \\
\text { Beta }\end{array}$} & \multirow[t]{2}{*}{$\bar{t}$} & \multirow[t]{2}{*}{ Sig. } \\
\hline & B & Std. Error & & & \\
\hline $\begin{array}{ll}1 & \text { (Constant) }\end{array}$ & 2.262 & .257 & & 8.787 & .000 \\
\hline $\begin{array}{l}\text { Headteachers' } \\
\text { Commitment }\end{array}$ & .045 & .061 & .060 & .742 & .459 \\
\hline
\end{tabular}

a. Dependent Variable: Learners' Performance

\section{Test of Hypothesis}

The research hypothesis stated that " $\mathrm{H}_{\mathrm{O} 1}$ : There is no statistically significant relationship between headteachers' commitment and learners' academic performance in primary schools." Since the $p$ value associated with headteachers' commitment was 0.459 , a value much higher than the test significance level of 0.05 , the null hypothesis is accepted. This output suggests that headteachers' commitment does not have statistically significant relationship with learners' academic performance in primary schools in Kericho County.

\section{CONCLUSIONS}

The study concludes that headteachers' commitment does not have statistically significant relationship with learners' academic performance in primary schools in Kericho County. This was mainly because in some of the primary schools, the headteachers failed to ensure proper coordination of teachers in their respective schools, were not friendly and easy to dialogue with in their respective schools, and were not open to criticism by staff, and were not effective in promoting co-operation among staff in their respective schools. Morever, in a number of schools, head teachers failed to ensure that teachers complete the syllabus, and were not effective in supervising and directing teachers, as well as allocating work to teachers. In some schools the primary schools the headteachers were not commited to developing personal strategies especially during difficult situations. Even though this was not the case in most of the schools, it was important the schools affected were assisted to enhance contribution of headteachers' towards their learners' academic performance in primary schools in Kericho County

\section{RECOMMENDATIONS}

The school management to consider reviewing priorities with respect to handling of matters related to personal welfare of all staff, as well as equality in treatment to staff members and aligning such priorities to learner performance.

The Ministry of Education to strengthen monitoring of school management practices by headteachers so as to check o inadequacies such as improper coordination of teachers in their respective schools, ineffective in promoting cooperation among staff in their respective schools, and ineffectiveness in supervising and directing teachers.

The school management should consider putting much emphasis update training programs aimed at enlighting the headteachers on the essence of giving subordinates personal attention, understanding teachers' individual differences and the need for creating a peaceful atmosphere at school.

\section{REFERENCES}

Alabu, P. F., 2013. Influence Of Headteachers' Personal Characteristics On Their Performance Of Administrative Tasks In Secondary Schools In Migori County. Doctoral dissertation, University of Nairobi.

Allen, N. J., and Meyer, J. P., 1992. The measurement and antecedents of affective, continuance and normative commitment to the organization. Journal of occupational psychology, 63(1), 1-18., 63(1), 1-18. 
Anderson, M., and Cawsey, C., 2008. Learning for leadership: Building a school of professional practice (Vol. 2). Aust Council for Ed Research.

Awiti, J., 2016. Influence of Headteachers' Selected Instructional Supervisory Practices on provision of quality education in Secondary schools in Kenya. Jaramogi Oginga Odinga University. Available at http://62.24.102.115:8080/xmlui/handle/1 23456789/308

Banerjee, A., and Chaudhury, S., 2010. Statistics without tears: Populations and samples. Industrial psychiatry journal, 19(1), 60.

Bass, B. M., and Bass, R., 2008. Handbook of leadership: Theory, research, and application. Free Press.

Beatriz, P., Deborah, N., and Hunter, M., 2008. Improving School Leadership, Volume 1 Policy and Practice: Policy and Practice (Vol. 1). OECD publishing.

Bett, D. R., 2018. Relationship between selected head teachers leadership styles, and academic performance of primary schools in Tindiret Sub-County, Nandi County, Kenya. Doctoral dissertation, Egerton University.

Blase, J., and Blase, J., 2002. The dark side of leadership: Teacher perspectives of principal mistreatment. Educational Administration Quarterly, 38(5), 671-727.

Bono, J. E., and Judge, T. A., 2004. Personality and transformational and transactional leadership: a meta-analysis. Journal of applied psychology, 89(5), 901.

Brown, A., 1992. Organizational culture: The key to effective leadership and organizational development. Leadership \& Organization Development Journal, 13(2), 3-6.

Burns, M., 2016. 7 Recommendations to Improve Teacher Professional Development in Fragile Contexts. Available at https://www.globalpartnership.org/blog/7recommendations-improve-teacher- professional-development-fragile-

\section{contexts}

Burns, R. P., and Burns, R., 2008. Business research methods and statistics using SPSS. Sage.

Day, C., 2011. Successful school leadership: Linking with learning and achievement. McGraw-Hill Education (UK).

Day, G. S., 2011. Closing the marketing capabilities gap. Journal of marketing, 75(4), 183-195.

Dös, I., and Savas, A. C., 2015. Elementary School Administrators and Their Roles in the Context of Effective Schools. SAGE Open, 5(1).

Glaze, S., 2014. For Effective Schools, Teamwork is Not Optional. Available at https://www.edutopia.org/blog/effectiveschools-teamwork-not-optional-seanglaze

Hamilton, M., 2010. The interaction of transactional and transformational leadership. Online Journal for Workforce Education and Development, 3(3), 4.

Herrera, R., 2010. Principal leadership and school effectiveness: Perspectives from principals and teachers.

Hill, L., 2012. The Value of Workshops and Continuing Education for Teachers. https://evolllution.com/opinions/the-valueof-workshops-and-continuing-educationfor-teachers/

Ibua, M. P., 2014. The influence of institutional factors and job-related attitudes in relationship between employee empowerment and performance of universities in Kenya. NAIROBI UNIVERSITY.

Igella, R., 2014. Factors influencing employee commitment: A case of Kenya civil aviation authority. Doctoral dissertation, United States International UniversityAfrica. 
Jaros, S., 2007. Meyer and Allen model of organizational commitment: Measurement issues. The Icfai Journal of Organizational Behavior, 6(4), 7-25.

Jaros, S., 2007. Meyer and Allen model of organizational commitment: Measurement issues. The Icfai Journal of Organizational Behavior, 6(4), 7-25.

Judge, T. A., and Piccolo, R. F., 2004. Transformational and transactional leadership: a meta-analytic test of their relative validity. Journal of applied psychology, 89(5), 755.

Judge, T. A., Erez, A., Bono, J. E., and Thoresen, C. J., 2003. The core self-evaluations scale: Development of a measure. Personnel psychology, 56(2), 303-331.

Kara, L., 2013. Head Teacher's Role in Managing Conflict among Teaching Staff in Public Secondary Schools in Thika District, Kiambu County, Kenya. Kenyatta University.

Karaca, H., 2010. The Effects Of Transformational Leadership On Employees' Perceived Leadership Effectiveness In Organizations Federal Emergency Management Agency Case.

Keskes, I., 2014. Relationship between leadership styles and dimensions of employee organizational commitment: A critical review and discussion of future directions. Intangible Capital, 10(1).

Kihara, M. P., 2017. Influence of strategy implementation on the performance of Manufacturing small and medium firms in Kenya. Doctoral dissertation, COHRED, JKUAT.

Kim, K., Altmann, J., and Hwang, J., 2010. Measuring and analyzing the openness of the Web2. 0 service network for improving the innovation capacity of the Web2. 0 system through collective intelligence. In On Collective Intelligence , 93-105.
Kothari, C. R., 2003. Research Methodology: Methods and Techniques. New Delhi: Wishwa Prakashan.

Labaree, R. V., 2009. Research Guides: Organizing Your Social Sciences Research Paper: Types of Research Designs.

Leithwood, K., and Riehl, C., 2003. What do we already know about successful school leadership. In annual meeting of the American Educational Research Association, Chicago, IL, Vol. 22.

Leithwood, K., Seashore, K., Anderson, S., and Wahlstrom, K., 2004. Review of research: How leadership influences student learning.

Lo, M. C., Thurasamy, R., and Liew, W. T., 2014. Relationship between bases of power and job stresses: Role of mentoring. SpringerPlus, 3(1), 432.

Lok, P., and Crawford, J., 2004. The effect of organisational culture and leadership style on job satisfaction and organisational commitment: A crossnational comparison. Journal of management development, 23(4), 321338.

Lunenburg, F. C., 2011. Goal-setting theory of motivation. International journal of management, business, and administration, 15(1), 1-6.

Magak, E. O., 2013. Challenges facing head teachers in financial management in secondary schools: A case of Kisumu East District Kenya. Unpublished MEAP project, University of Nairobi, Kenya.

Meyer, J. P., Srinivas, E. S., Lal, J. B., and Topolnytsky, L., 2007. Employee commitment and support for an organizational change: Test of the three-component model in two cultures. Journal of occupational and organizational psychology, 80(2), 185211. 
Meyer, K. E., and Peng, M. W., 2005. Probing theoretically into Central and Eastern Europe: Transactions, resources, and institutions. Journal of international business studies, 36(6), 600-621.

Nath, Gangai, K., and Agrawal, R., 2015. Job satisfaction and organizational commitment: Is it important for employee performance. International journal of management and business research, 5(4), 269-278.

Norman, D., 2013. The design of everyday things: Revised and expanded edition. Basic books.

Nzambi, P., 2012. Role of the Headteacher in Instructional Supervision as Perceived by Teachers in Secondary Schools in Kitui District, Kitui County-Kenya. Kenyatta University
Pandey, C. K., 2012. Impact of job satisfaction and organizational commitment on employee loyalty. International Journal of Social Science \& Interdisciplinary Research, 1(8), 26-41.

Rehman, R. R., and Waheed, A., 2012. Transformational leadership style as predictor of a decision making styles: Moderatig role of emotional intelligence. Pakistan Journal of Commerce and Social Sciences (PJCSS), 6(2), 257-268.

Robinson, J., 2011. Leadership in Small Primary Schools: the Headteacher's Perspective. University of Hertfordshire.

Wadesango, N. Mutekwe, E. Ndofirepi, A. Maphosa, C. and Machingambi, S., 2017. Involvement of teachers in schoolbased decision making processes of choice of subjects. International Journal of Educational Sciences, 8(3), 645-653. 